\title{
Acid-promoted direct C-C coupling of 1,3-diazines and 1,2,4- triazines with aryl-containing macrocyclic compounds and their open-chain analogues
}

\author{
Nadezhda A. Itsikson, Dmitry G. Beresnev, Gennady L. Rusinov, and \\ Oleg N. Chupakhin* \\ I.Postovsky Institute of Organic Synthesis of RAS, \\ 22/20, S. Kovalevskaya / Akademicheskaya st., GSP-147, Ekaterinburg, 620219, Russia \\ E-mail: chupakhin@ios.uran.ru
}

Dedicated to Professor Alexander I. Konovalov on the occasion of his $70^{\text {th }}$ birthday

(received 23 Mar 04; accepted 27 July 04; published on the web 29 July 04)

\begin{abstract}
A method of direct C-C coupling of azahetarenes with macrocycles (calix[4]arene, benzo-12crown-4, 1,5-bis(2,6-dimethylphenoxy)-3-oxapentane), based on the nucleophilic addition to unsubstituted carbon atom in azines, has been developed.
\end{abstract}

Keywords: Calix[4]arene, benzo-12-crown ether, 1,3-diazine, 1,2,4-triazine, nucleophilic addition to unsubstituted carbon atom in azine

\section{Introduction}

Macrocyclic compounds exhibit a large variety of functions: e.q. as building inclusion compounds and selective complexing agents for metal ions. ${ }^{1,2}$ Modification of such molecules by heterocyclic fragments makes it possible to increase their receptor ability and improve biological activity. For example, calix[4]arenes, containing imidazole moieties, have lately attracted considerable interest because of their potential as enzyme mimics. ${ }^{3}$ Much attention has been paid to the use of heterocycle-containing crown ethers in biological environments and for binding to biomolecules. ${ }^{4}$

Earlier multistage processes have been based on consecutive building of a heterocyclic fragment onto a macrocyclic matrix by cyclization of open-chain structures or by nucleophilic substitution of the heterocycle by action of nucleophilic groups in the macrocycle. Recently we have worked out the method of one-stage modification of benzo crown ethers, their open-chain podand analogues or resorcinearenes by 1,2,4-triazine derivatives which are one of the most active azaheterocycles. ${ }^{5,6}$ In the present work we have developed the method of nucleophilic 
addition of arenes to unsubstituted carbon atom in azines for one-step coupling of some hetarenes with aryl-containing macrocycles. ${ }^{7}$

For the first time it is shown that calix[4] arene can be used as a nucleophilic component in this reaction both with benzo crown ethers and aryl containing podands. Moreover, it is demonstrated that not only 1,2,4-triazines but also 1,3-diazines can be introduced in the process as the electrophile by the synthesis of new macrocycles contaning 1,2,4-triazine and 1,3-diazine units.

\section{Results and Discussion}

It has been found that in spite of the presence of aza-groups in the molecule both 1,3-diazines and 1,2,4-triazines usually do not react with aromatic C-nucleophiles. There are some methods for activation of azine ring to nucleophilic attack (protonation, acylation, introduction of electron withdrawing groups). ${ }^{7-9}$ To find out the optimal conditions for the functionalization of calix[4]arene with 3-methylthio-1,2,4-triazine (2a), 3-amino-1,2,4-triazine (2b) and quinazoline (2c), the interactions of azines with 2,6-dimethyl-phenol (1) as a model reaction were investigated (Scheme 1). In these reactions the corresponding very stable $\mathrm{A}_{\mathrm{N}}$-adducts $3 \mathrm{a}$-c were isolated.

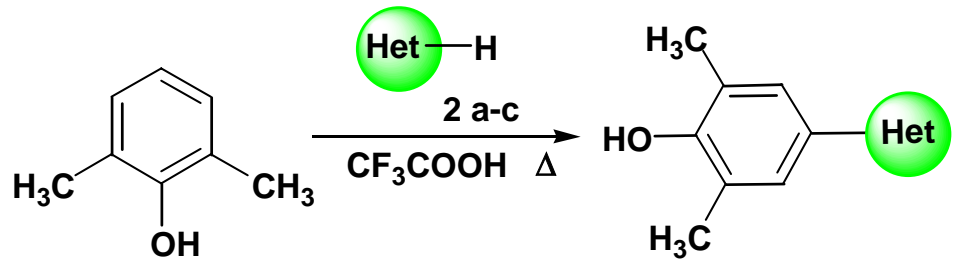

1

3 a-c

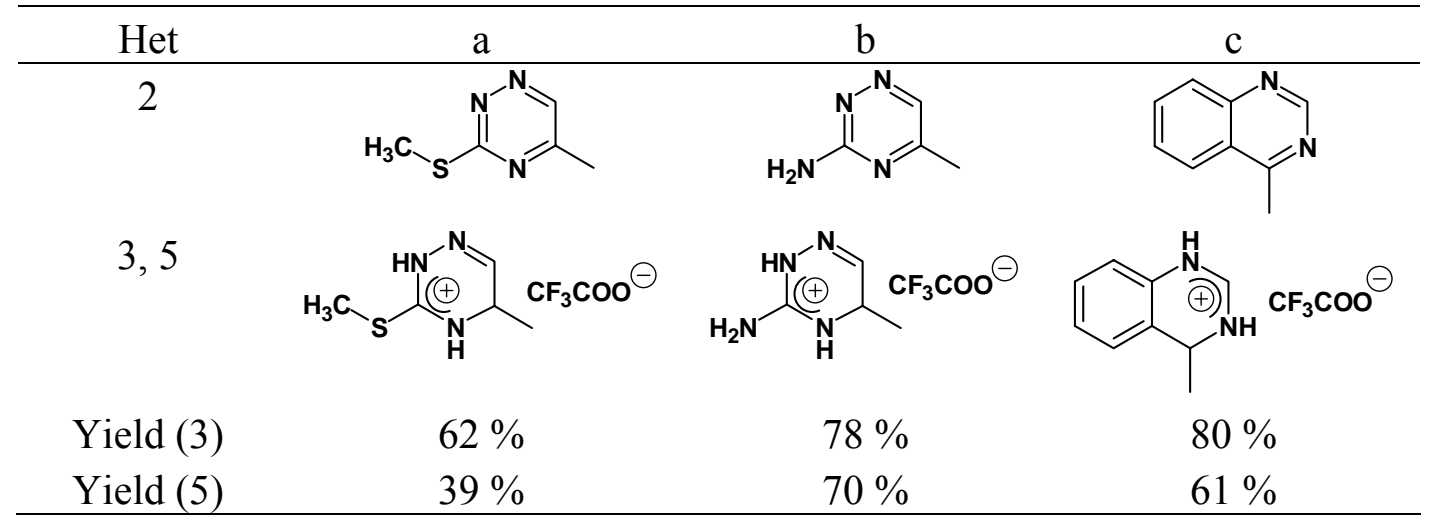

\section{Scheme 1}


Calixarene 4 can be considered as a phenol derivative, so it seems very promising to use this macrocycle as a nucleophilic component in $\mathrm{C}-\mathrm{C}$ coupling.

Thus, reaction of 4 with $2 \mathrm{a}-\mathrm{c}$ gives rise to exhaustive heteroarylation of the upper rim of calixarene producing 5a-c in moderate yields. (Scheme 1).

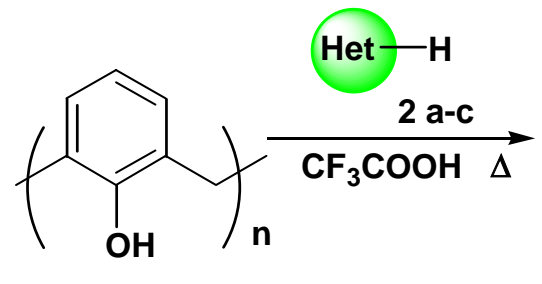

4

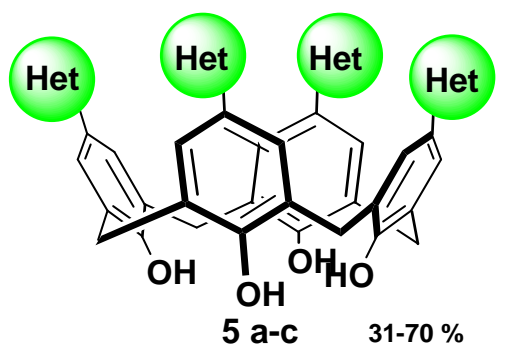

\section{Scheme 2}

The reaction involves protonation of the azine nitrogen atom by TFA followed by addition of an aromatic nucleophile. The trifluoroacetates obtained interact with calixarene to form highly stable products which are sparingly soluble in water.

The structures were assigned by ${ }^{1} \mathrm{H}$ and ${ }^{13} \mathrm{C}$ NMR-spectroscopy.

In 5a-b the signals of bridging methylene groups were located in the regions $\delta 3.85-3.88 \mathrm{ppm}$ and 4.10-4.23 ppm as a pair broad doublets with $J \sim 13 \mathrm{~Hz}$, which indicated the presence of the cone conformation. ${ }^{10,11}$ The saturated protons of the triazine and quinazoline rings appeared at $\delta$ 4.90-4.99 ppm and 5.7-5.8 ppm characteristic of addition products. The ${ }^{13} \mathrm{C}$ NMR spectra of 5a-b displayed a signal from the bridging methylene group at $\delta 32.1-32.8$ ppm supporting an adduct in the cone conformation

In 5c the protons of bridging methylene groups were located as two broadened singlets at $\delta$ 4.26-4.27 ppm and 3.33-3.34 ppm, The bridging methylene carbon signal appeared at $32.5 \mathrm{ppm}$ confirming the formation of an adduct in the cone conformation (bridging methylene groups of the 1,3-alternate conformation resonate at $37.7 \mathrm{ppm}$ ).

Benzo crown ethers and aryl-containing podands react with azines in a similar manner. The highly reactive $\mathrm{NH}$-azinium salts of $\mathbf{2 c - d}$, obtained in situ in trifluoroacetic acid solution, react with aryl polyethers 6 to give the stable $\sigma^{\mathrm{H}}$-adducts 7c-d in 51-58 \% yield (Scheme 3).

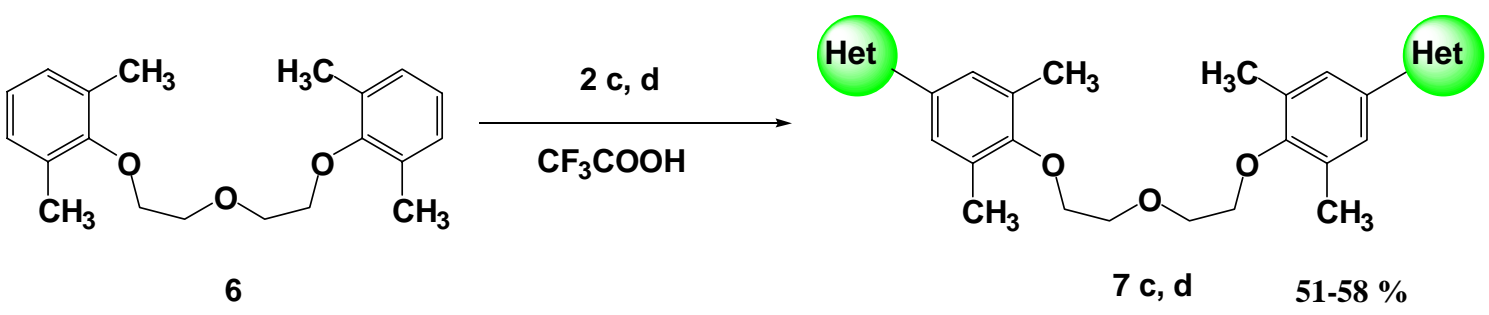




Yield (7) $\quad 10$

\section{Scheme 3}

Compound $7 \mathrm{~d}$ with two pyrimidine rings was the main product while the substance 8 with one pyrimidine ring was isolated in $11 \%$ yield.

The coupling of benzo-12-crown-4 (9) with protonated 1,3-diazines takes place under the same conditions and results in hetaryl-containing crown ethers 10c-d (Scheme 4). These addition products are stable unlike the corresponding 1,2,4-triazinederivatives. ${ }^{12}$

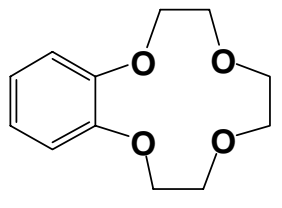

9

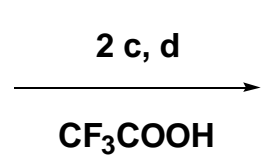

Het

$10 \mathrm{c}, \mathrm{d}$

\section{Scheme 4}

As expected, pyrimidine and quinazoline were less reactive in the reaction with aromatic polyethers than with phenols. Thus, complete conversion of quinazoline with aromatic polyethers took place in $48 \mathrm{~h}$ while $4 \mathrm{~h}$ was sufficient for the reaction with phenol and resorcinol derivatives. This may be due to the sterical hindrance and unconcerted orientation of substituents in the benzo-12-crown-4.

The saturated protons absorbed in the region $\delta 5.52-6.30 \mathrm{ppm}$. The location of the $\mathrm{C} 2-\mathrm{H}$ signals at the $\delta 8.4-8.7 \mathrm{ppm}$ indicated formation of a $\mathrm{C}-\mathrm{C}$ bond between pyrimidine $\mathrm{C} 4$ and the aromatic ring of the polyether.

In summary, a convenient one-step method for acid-promoted functionalization of macrocycles such as calix[4]arene, crown ethers and their open-chain podand analogues by nucleophilic addition to the unsubstituted carbon atom of 1,3-diazine and 1,2,4-triazine derivatives has been developed. 


\section{Experimental Section}

General Procedures. Flash chromatography was performed on Kieselgel Woelm DC silica gel using $\mathrm{CH}_{2} \mathrm{Cl}_{2}-\mathrm{CH}_{3} \mathrm{OH}$ as an eluent. All melting points were measured on a Boetius melting point apparatus and are uncorrected. Elemental analyses were performed on a Perkin Elmer CHNO Analyzer PE 2400. ${ }^{1} \mathrm{H}$ and ${ }^{13} \mathrm{C}$ NMR spectra were recorded on a Bruker DRX 400 spectrometer with TMS as an internal standard.

3-Amino-1,2,4-triazine and benzo-12-crown-4 were a Lancaster Synthesis Ltd. chemical. 3Methylthio-1,2,4-triazine (2a), 3-methylthio-4,5-dihydro-5-(2,6-dimethylphenol-4)-1,2,4triazinium trifluoroacetate (3a) and 3-amino-4,5-dihydro-5-(2,6-dimethylphenol-4)-1,2,4triazinium trifluoroacetate (3b) were synthesized according to [13] and [9] correspondingly.

4-(2,6-Dimethylphenol)-3,4-dihydroquinazolinium trifluoroacetate (3c). Quinazoline (40 mg, $0.31 \mathrm{mmol}$ ) and 2,6-dimethylphenol $(38 \mathrm{mg}, 0.31 \mathrm{mmol})$ were suspended in $4.5 \mathrm{~mL}$ of a mixture of benzene and trifluoroacetic acid $(2: 1)$. The mixture was stirred at room temperature until complete dissolution of the starting materials. A colorless precipitant was formed 40 min later. Filtration, washing with benzene and drying in air gave $80 \%$ of 3c, mp $187-189{ }^{\circ} \mathrm{C}$. Anal. calcd. for $\mathrm{C}_{18} \mathrm{H}_{17} \mathrm{~F}_{3} \mathrm{~N}_{2} \mathrm{O}_{3}, \%$ : C, 59.02; H, 4.66; N, 7.65. Found, \%: C, 59.21; H, 4.66; N, 7.46. NMR ${ }^{1} \mathrm{H}$ (DMSO-d ${ }_{6}$ ), $\delta$ (ppm): 8.45 (s, 1H, C $\left.{ }^{2}-\mathrm{H}\right), 7.30-7.34$ (m, 1H, Quin), 7.17-7.29 (m, 2H, Quin), 6.95-6.96 (m, 1H, Quin), 6.94 (s, 2H, Ph), $5.94\left(\mathrm{~s}, 1 \mathrm{H}, \mathrm{C}^{4}-\mathrm{H}\right), 2.16\left(\mathrm{~s}, 6 \mathrm{H}, \mathrm{CH}_{3}\right)$.

4-[3-Methylthio-4,5-dihydro-5-(1,2,4-triazinio)]calix[4]arene tetrakis(trifluoroacetate) (5a). 3-Methylthio-1,2,4-triazine (60 mg, $0.47 \mathrm{mmol})$ and calix[4]arene $(50 \mathrm{mg}, 0.11 \mathrm{mmol})$ were suspended in $2 \mathrm{~mL}$ of trifluoroacetic acid. The mixture was refluxed for $4.5 \mathrm{~h}$ to complete dissolving of the starting compounds. The solvent was removed in vacuo and the residue recrystallized from water. Yield $39 \% \mathrm{mp} 212{ }^{\circ} \mathrm{C}$ (decomp.). Anal. calcd. for $\mathrm{C}_{52} \mathrm{H}_{48} \mathrm{~N}_{12} \mathrm{~F}_{12} \mathrm{O}_{12} \mathrm{~S}_{4}, \%$ : C, 44.96; H, 3.48; N, 12.10. Found, \%: C, 44.57; H, 3.69; N, 11.80. NMR ${ }^{1} \mathrm{H}\left(\mathrm{DMSO}-\mathrm{d}_{6}\right), \delta$ (ppm): 7.19 (br.s, 4H, C $\left.{ }^{6}-\mathrm{H}\right), 4.99$ (br.s, 4H, C $\left.-\mathrm{H}\right), 7.02$ (s, 8H, Ar), 3.85-3.88 (dd) and 4.10-4.21 (dd) $\left(8 \mathrm{H}, \mathrm{CH}_{2}-\right), 2.61$ (s, 12H, SMe).

4-[3-Amino-4,5-dihydro-5-(1,2,4-triazinio)]calix[4]arene tetrakis(trifluoroacetate) (5b). 3Amino-1,2,4-triazine $(271 \mathrm{mg}, 2.82 \mathrm{mmol})$ and calix[4]arene (150 mg, $0.354 \mathrm{mmol})$ were dissolved in a mixture of $3 \mathrm{~mL}$ of chloroform and $1 \mathrm{~mL}$ of trifluoroacetic acid. The mixture was refluxed for $12 \mathrm{~h}$. The solvent was removed in vacuo. The residue was washed with water and recrystallized from water to give $70 \%$ of $5 \mathbf{b}, \mathrm{mp} 200{ }^{0} \mathrm{C}$ (decomp.). Anal. calcd. for $\mathrm{C}_{48} \mathrm{H}_{44} \mathrm{~N}_{16} \mathrm{~F}_{12} \mathrm{O}_{12}$, \%: C, 45.58; H, 3.51; N, 17.72. Found, \%: C, 45.11; H, 3.78; N, 17.46. NMR ${ }^{1} \mathrm{H}$ (DMSO-d (D) $\delta$ (ppm): 7.08 (br.s, 4H, C ${ }^{6}-\mathrm{H}$ ), 4.90 (br.s, 4H, C $\left.{ }^{5}-\mathrm{H}\right), 6.59$ (s, 8H, Ar), 3.82-3.85 (dd) and 4.10-4.23 (dd) $\left(8 \mathrm{H}, \mathrm{CH}_{2}-\right), 9.28$ (br.s, 4H, N $\left.{ }^{4}-\mathrm{H}\right) . \mathrm{NMR}^{13} \mathrm{C}\left(\mathrm{DMSO}-\mathrm{d}_{6}\right), \delta$ (ppm): 31.33 , 31.68, 31.93, $32.80\left(\mathrm{CH}_{2}\right)$; 50.31, 50.43, 50.63, $50.72\left(\mathrm{C}_{\text {triaz }}^{5}\right) ; 111.92,114.86,117.23,117.80$ $\left(\mathrm{CF}_{3} \mathrm{COO}\right) ; 158.91,159.25,159.59,159.86\left(\mathrm{CF}_{3} \mathrm{COO}\right) ; 127.89-131.70(\mathrm{Ar}) ; 142.80(\mathrm{C}-\mathrm{OH})$; $149.25,149.28,149.41,149.60\left(C_{-} C^{5}\right) ; 158.91,159.25,159.59,159.86\left(C^{3}\right)$ 
4-(3,4-Dihydro-4-quinazolinio)calix[4]arene tetrakis(trifluoroacetate) (5c). Quinazoline (100 $\mathrm{mg}, 0.77 \mathrm{mmol}$ ) and calix[4]arene $(82 \mathrm{mg}, 0.19 \mathrm{mmol})$ were dissolved in $3 \mathrm{~mL}$ of trifluoroacetic acid. The mixture was heated to reflux for $4 \mathrm{~d}$. The solvent was removed in vacuo. The residue was recristallized from water. to give $61 \%$ of $5 \mathrm{c}, \mathrm{mp}>250^{\circ} \mathrm{C}$. Anal. calcd. for $\mathrm{C}_{68} \mathrm{H}_{52} \mathrm{~F}_{12} \mathrm{~N}_{8} \mathrm{O}_{12} \bullet 12 \mathrm{H}_{2} \mathrm{O}$, \%: C, 50.50; H, 4.74; N, 6.93. Found, \%: C, 51.33; H, 3.90; N, 6.97. NMR ${ }^{1} \mathrm{H}\left(\mathrm{DMSO}_{\mathrm{d}}\right), \delta(\mathrm{ppm}): 8.37$ (m, 1H, C(2)-H), 6.82-7.36 (m, 6H, CH(Ar), $\mathrm{CH}_{\text {Quinazoline }}$ ), 5.76-5.80 (m, 1H, C(4)-H), 4.26-4.27 (m) and 3.33-3.34 (m) $\left(2 \mathrm{H}, \mathrm{CH}_{2}\right) . \mathrm{NMR}^{13} \mathrm{C}\left(\mathrm{DMSO}-\mathrm{d}_{6}\right), \delta$ (ppm): $32.25\left(\mathrm{CH}_{2}\right), 54.62\left(\mathrm{C}^{4}\right), 115.05\left(\mathrm{CF}_{3} \mathrm{COOH}\right), 157.85\left(\mathrm{CF}_{3} \mathrm{COOH}\right), 116.85,117.98$, 121.93, 127.02, 127.94, 128.95, 129.62, 130.06, 130.18, 132.10, 132.19, 147.86, 154.99 (Ar).

1,5-bis(2,6-Dimethylphenoxy)-3-oxapentane (6). $\mathrm{NaOH}(4.0 \mathrm{~g}, 0.1 \mathrm{~mol})$ was added to a stirred solution of 2,6-dimethylphenol (12.2 g, $0.1 \mathrm{~mol})$ in $150 \mathrm{~mL}$ of DMF. The mixture was stirred under argon atmosphere until dissolution of the $\mathrm{NaOH}$. Then a solution of $7.15 \mathrm{~g}(0.05 \mathrm{~mol}) \beta, \beta{ }^{\prime}-$ dichloroethyl ether in $20 \mathrm{~mL}$ of DMF was added dropwise over $30 \mathrm{~min}$. The reaction mixture was heated to $110-115{ }^{\circ} \mathrm{C}$ and stirred for $20 \mathrm{~h}$ at this temperature. The precipitate was filtered and washed with water. The product was purified by column chromatography using dichloromethane as an eluent to give $60 \%$ of 6, mp 31-32 ${ }^{0} \mathrm{C}$. Anal. calcd. for $\mathrm{C}_{20} \mathrm{H}_{26} \mathrm{O}_{3}, \%$ : C, 76.43; H, 8.28. Found: C, 76.19; H, 8.45. 6.99 (m, 4H, Ar), 6.89 (dd, J=6.9 Hz, J=8.0 Hz, 2H, Ar), 3.88-3.90 (m, 4H, $\left.\mathrm{ArOCH}_{2} \mathrm{CH}_{2}\right), 3.75-3.90\left(\mathrm{~m}, 4 \mathrm{H}, \mathrm{ArOCH}_{2} \mathrm{CH}_{2}\right), 2.24\left(\mathrm{~s}, 12 \mathrm{H}, \mathrm{CH}_{3}\right)$.

\section{1,5-bis(2,6-Dimethyl-(3,4-dihydroquinazolinium)-phenoxy)-3-oxapentane trifluoroacetate} (7c). Quinazoline (60 mg, $0.46 \mathrm{mmol}$ ) and 1,5-bis(2,6-dimethylphenoxy)-3-oxapentane (72 mg, $0.23 \mathrm{mmol}$ ) were dissolved in $3 \mathrm{~mL}$ of trifluoroacetic acid. The mixture was stirred at the room temperature for $2 \mathrm{~d}$. The solvent was removed in vacuo. The residue was washed by 2-propanole purified by flash chromatography using $\mathrm{CH}_{2} \mathrm{Cl}_{2}-\mathrm{C}_{2} \mathrm{H}_{5} \mathrm{OH}(50: 1)$ as an eluent to give $51 \%$ of 7c, mp 89-91 ${ }^{0} \mathrm{C}$. Anal. calcd. for $\mathrm{C}_{40} \mathrm{H}_{40} \mathrm{~F}_{6} \mathrm{~N}_{4} \mathrm{O}_{7} \bullet \mathrm{H}_{2} \mathrm{O}, \%$ : C, 58.18; H, 5.11; N, 6.78. Found, \%: C, 58.47; H, 5.18; N, 6.33. NMR ${ }^{1} \mathrm{H}\left(\mathrm{DMSO}_{\mathrm{d}}\right), \delta(\mathrm{ppm}): 8.48$ (s, 1H, C(2)-H), 7.22-7.42 (m, 2H), 7.12-7.16 (m, 1H), 6.84-6.97 (m, 3H), 5.96 (s, 1H, C(4)-H), 3.89 (br.s, 2H, $\left.\mathrm{OCH}_{2}\right), 3.79$ (br.s, $\left.2 \mathrm{H}, \mathrm{OCH}_{2}\right), 2.24\left(\mathrm{~s}, 6 \mathrm{H}, \mathrm{CH}_{3}\right)$.

1,5-bis-(2,6-Dimethyl-4-(3,4-dihydropyrimidinium) phenoxy)-3-oxapentane trifluoroacetate (7d) and 1-(2,6-dimethyl-4-(3,4-dihydropyrimi-dinium)-phenoxy)-3-oxapentane trifluoroacetate (8). Pyrimidine (150 mg, $1.87 \mathrm{mmol}$ ) and 1,5-bis(2,6-dimethylphenoxy)-3-oxapentane (294 mg, $0.94 \mathrm{mmol}$ ) were dissolved in $3 \mathrm{~mL}$ of trifluoroacetic acid. The mixture was refluxed for $7 \mathrm{~d}$. The solvent was removed in vacuo and the product purified by flash chromatography using $\mathrm{CH}_{2} \mathrm{Cl}_{2}-$ $\mathrm{C}_{2} \mathrm{H}_{5} \mathrm{OH}(50: 1)$ as an eluent to give $58 \%$ of $\mathbf{6 d}$ as a yellowish oil. NMR ${ }^{1} \mathrm{H}$ (DMSO-d $\left.\mathrm{d}_{6}\right), \delta$ (ppm): 8.79 (d, $J=5.3 \mathrm{~Hz}, 1 \mathrm{H}, \mathrm{C}(2)-\mathrm{H}), 7.01-7.09(\mathrm{~m}), 6.99-7.01$ (m), 6.88-6.92 (m) (4H, $\left.\mathrm{CH}_{\text {Aromatic }}\right), 6.42(\mathrm{~d}, J=8 \mathrm{~Hz}, 1 \mathrm{H}, \mathrm{C}(4)-\mathrm{H}), 3.89-4.00\left(\mathrm{~m}, 2 \mathrm{H}, \mathrm{OCH}_{2}\right), 3.76-3.81\left(\mathrm{~m}, 2 \mathrm{H}, \mathrm{OCH}_{2}\right)$, $2.24\left(\mathrm{~m}, 6 \mathrm{H}, \mathrm{CH}_{3}\right)$. The next raction contained $11 \%$ of 7 as a yellowish oil. Anal. calcd. for $\mathrm{C}_{26} \mathrm{H}_{31} \mathrm{~F}_{3} \mathrm{~N}_{2} \mathrm{O}_{5} \bullet 0,5 \mathrm{H}_{2} \mathrm{O}$, \%: C, 60.34; H, 6.23; N, 5.41. Found, \%: C, 60.97; H, 6.72; N, 5.12. NMR ${ }^{1} \mathrm{H}\left(\mathrm{DMSO}_{\mathrm{d}}\right), \delta(\mathrm{ppm}): 8.01$ (dd, $\left.J=2.3 \mathrm{~Hz}, 7.6 \mathrm{~Hz}, 0.5 \mathrm{H}, \mathrm{C}(2)-\mathrm{H}\right), 8.79$ (d, J=7.6Hz, 0.5H, C(2)-H), 6.88-7.095 (m, 7H, Ar, Pyr), 4.60 (dd, J=2.3Hz, 7.6Hz, 0.5H, C(4)-H), 4.96 (d, 
$J=3.3 \mathrm{~Hz}, 0.5 \mathrm{H}, \mathrm{C}(4)-\mathrm{H}), 6.15(\mathrm{~d}, J=7.6 \mathrm{~Hz}, 0.5 \mathrm{H}, \mathrm{N}(2)-\mathrm{H}), 3.76-3.99\left(\mathrm{~m}, 8 \mathrm{H}, \mathrm{CH}_{2}\right) ; 2.19-2.23$ $(\mathrm{m}, 12 \mathrm{H}, \mathrm{Ac})$.

4-[(Benzo-12-crown-4)-4'-yl]-1(3),4-dihydoquinazolinium trifluoroacetate (10c). Quinazoline (40 $\mathrm{mg}, 0.31 \mathrm{mmol})$ and benzo-12-crown-4 $(69 \mathrm{mg}, 0.31 \mathrm{mmol})$ were dissolved in the mixture of 1,5 $\mathrm{mL}$ of benzene and $1,5 \mathrm{~mL}$ of trifluoroacetic acid. The mixture was stirred at the room temperature for $2 \mathrm{~d}$. The solvent was removed in vacuo and the residue washed with 2-propanole to give $57 \%$ of $10 \mathrm{c}, \mathrm{mp} 194-195{ }^{0} \mathrm{C}$. Anal. calcd. for $\mathrm{C}_{22} \mathrm{H}_{23} \mathrm{~N}_{2} \mathrm{~F}_{3} \mathrm{O}_{6}, \%$ : C, 56.41; $\mathrm{H}, 4.95 ; \mathrm{N}$, 5.98. Found, \%: C, 55.98; H, 5.39; N, 5.56. NMR ${ }^{1} \mathrm{H}$ (DMSO-d $\left.{ }_{6}\right), \delta(\mathrm{ppm}): 8.47(\mathrm{~s}, 1 \mathrm{H}, \mathrm{C}(2)-\mathrm{H})$, 7.27-7.31 (m, 1H), 7.14-7.21 (m, 2H), 7.05-7.06 (m, 1H), 6.89-7.00 (m, 3H), 6.01 (s, 1H, C(4)$\mathrm{H})$, 4.07-4.13 (m, 4H, OCH 2$), 3.72-3.74\left(\mathrm{~m}, 4 \mathrm{H}, \mathrm{OCH}_{2}\right), 3.63-3.66\left(\mathrm{~m}, 4 \mathrm{H}, \mathrm{OCH}_{2}\right)$.

4(6)-[(Benzo-12-crown-4)-4'-yl]-3,4(6)-dihydropyrimidinium trifluoroacetate and 4(6)[(benzo-12-crown-4)-4'-yl]-1,4-dyhydropyrimidinium trifluoroacetate (10d). Pyrimidine (150 mg, $1.87 \mathrm{mmol})$ and benzo-12-crown-4 $(419 \mathrm{mg}, 1.87 \mathrm{mmol})$ were dissolved in $3 \mathrm{~mL}$ of trifluoroacetic acid. The mixture was refluxed for $10 \mathrm{~d}$. The solvent was removed in vacuo and the product purified by flash chromatography using $\mathrm{CH}_{2} \mathrm{Cl}_{2}-\mathrm{C}_{2} \mathrm{H}_{5} \mathrm{OH}(20: 1)$ as an eluent to give $63 \%$ of $\mathbf{1 0 d}$ as an oil. Anal. calcd. for $\mathrm{C}_{18} \mathrm{H}_{21} \mathrm{~F}_{3} \mathrm{~N}_{2} \mathrm{O}_{6}, \%$ : C, 51.68; H, 5.06; N, 6.70. Found, \%: C, 51.24; H, 5.39; N, 6.56. NMR ${ }^{1} \mathrm{H}\left(\mathrm{DMSO}_{\mathrm{d}}\right), \delta(\mathrm{ppm}): 8.80(\mathrm{~s}, 1 \mathrm{H}, \mathrm{C}(2) \mathrm{H}), 8.79$ $(\mathrm{s}, 1 \mathrm{H}, \mathrm{C}(2) \mathrm{H}), 6.42-6.44$ (set of dublets, $2 \mathrm{H}, \mathrm{C}(4) \mathrm{H}), 6.90-7.23$ (m, 10H, C(5)-H, C(6)-H, Ar); 3.61-4.21 (m, 24H, $\left.\mathrm{OCH}_{2} \mathrm{CH}_{2}\right)$.

\section{Acknowledgements}

This work was possible due to financial support from Russian Foundation for Basic Research (Grants No 02-03-32332), President of the Russian Federation (Program for Support of Leading Scientific Schools, Grant RF NSh 1766.2003.3), ISTC (Project No 708) and CRDF (Grant No REC-005). A fellowship to Professors Alexander I. Konovalov and Igor S. Antipin from the A.E. Arbuzov Institute of Organic and Physical Chemistry (Kazan) is also gratefully acknowledged for fruitful discussion. We would like to thank Prof. L. Brandsma for supplying the pyrimidine, Prof. Igor S. Antipin for supplying calix[4]arene, Pavel V. Plekhanov for supplying quinazoline. Prof. Mikael Begtrup is acknowledged for improvements to English.

\section{References}

1. Hartley, J. H.; James, T. D.; Ward, C. J. J. Chem. Soc., Perkin 1 2000, 3155.

2. Molenveld, P.; Engbersen, J. F. J.; Reinhoudt, D. N. Chem. Soc. Rev. 2002, 29, 75.

3. Molenveld, P.; Engbersen, J. F. J.; Kooijman,H.; Spek, A. L.; Reinhoudt, D. N. J. Am. Chem. Soc. 1998, 120, 6726.

4. Fenniri, H.; Hosseini, M. W.; Lehn, J.-M. Helv. Chim. Acta 1997, 80, 786. 
5. Rusinov, G. L.; Beresnev, D. G.; Itsikson, N. A.; Chupakhin, O. N. Heterocycles 2001, 55, 2349.

6. Itsikson, N. A.; Rusinov, G. L.; Beresnev, D. G.; Chupakhin, O. N. Heterocycles 2003, 61, 593.

7. Chupakhin, O. N.; Charushin, V. N.; van der Plas, H. C. Nucleophilic Aromatic Substitution of Hydrogen; Academic Press: San Diego, 1994.

8. Girke, W. P. K. Chem. Ber. 1979, 112, 1348.

9. Rusinov, G. L.; Beresnev, D. G.; Chupakhin, O. N. Russ. J. Org. Chem. 1998, 34, 450.

10. Casnati, A.; de Mendoza, J.; Reinhoudt, D. N.; Ungaro, R. Determination of calixarene conformations by means of NMR techniques In NMR In Supramolecular Chemistry; Kluwer Academic Publishers: Dordrecht, 1999, p 307.

11. Shinkai, S.; Functionalized Calixarenes: New Application as Catalysts, Ligands, and Host Molecules In Calixarenes: a Versatile Class of Macrocyclic Compounds; Kluwer Academic Publishers: Dordrecht, 1991, p173.

12. Chupakhin, O. N.; Rusinov, G. L.; Beresnev, D. G.; Itsikson, N. A. Russ. J. Org. Chem. 1999, 35, 1253.

13. Paudler, W. W.; Chen, T.-K. J. Heterocycl. Chem. 1970, 7, 767. 